\title{
Differential response of benthic meiofauna to anoxia with special reference to Foraminifera (Protista: Sarcodina)
}

\author{
L. Moodley ${ }^{1, *}$, G. J. van der Zwaan ${ }^{2,3}$, P. M. J. Herman ${ }^{1}$, L. Kempers ${ }^{3}$, \\ P. van Breugel ${ }^{1}$
}

${ }^{1}$ Netherlands Institute of Ecology, Centre for Estuarine and Coastal Ecology (NIOO-CEMO), PO Box 140, 4400 AC, Yerseke, The Netherlands

${ }^{2}$ Department of Geology, Institute of Earth Sciences, Utrecht University, Budapestlaan 4, 3584 CD, Utrecht, The Netherlands

${ }^{3}$ Department of Biogeology, Faculty of Sciences, University of Nijmegen, PO Box 9010 ED, Nijmegen, The Netherlands

\begin{abstract}
Sediments collected from the northwestern Adriatic Sea (Mediterranean) were exposed to anoxic bottom-water conditions for more than 2 mo in order to examine the resistance of dominant meiobenthic taxa to prolonged anoxia. Copepods appeared to be most sensitive to anoxia, with densities being reduced to zero within $11 \mathrm{~d}$. Compared to oxic conditions, densities of both nematodes and soft-shelled foraminifera were significantly lower under prolonged anoxia. In contrast, total hardshelled foraminiferal densities did not differ significantly. This differential response resulted in a change in the meiobenthic community structure which was apparent after 1 mo. The change is reflected, and can be followed, in the foraminifera:nematode ratio, which is proposed as a bio-indicator of prolonged anoxia. The results clearly demonstrate that, among the meiobenthos, hard-shelled foraminifera are most resistant to prolonged anoxia. However, conditions resulting from the anoxic treatment (e.g. decreased biological interactions) were beneficial to some foraminiferal genera. This resulted in a shift in faunal patterns eventually leading to a strong reduction in foraminiferal generic diversity. Results also indicated that details of these trends may not be evident if only the part of the foraminiferal assemblage retained on a $63 \mu \mathrm{m}$ sieve is examined.
\end{abstract}

KEY WORDS: Anoxia $\cdot$ Meiobenthos $\cdot$ Foraminifera $\cdot$ Experiments

\section{INTRODUCTION}

Bottom waters depleted in oxygen are found worldwide, with the incidence and extent of such areas in coastal waters increasing due to eutrophication (Tyson \& Pearson 1991, Justic et al. 1993, Diaz \& Rosenberg 1995). The phenomenon of severe oxygen depletion is of great significance since it alters both the benthic community structure and energy flow (Diaz \& Rosenberg 1995). In shallow coastal areas characterized both by seasonal thermal or salinity stratification and relatively high primary production seasonal depletion of oxygen in the bottom waters is a recurrent feature (e.g.

\footnotetext{
•E-mail: moodley@cemo.nioo.knaw.nl
}

in the northern Adriatic Sea; Justic et al. 1993). The literature on ecological effects of hypoxia and anoxia on the meiobenthos is limited (Diaz \& Rosenberg 1995) but, overall, it seems that meiofaunal taxa are less affected by hypoxia than macrofauna and megafauna (e.g. Elmgren 1975, Josefson \& Widbom 1988, Levin et al. 1991).

In this study, the resistance to prolonged anoxia of dominant meiobenthic taxa from the northwestern Adriatic Sea is examined. In the northwestern Adriatic Sea, nematodes and foraminifera (soft and hard shelled) together constitute more that $95 \%$ of the meiobenthic community throughout the year (Moodley et al. in press a). Although benthic foraminifera are prevalent members of the meiobenthic community, they are not often included in general benthos studies. 


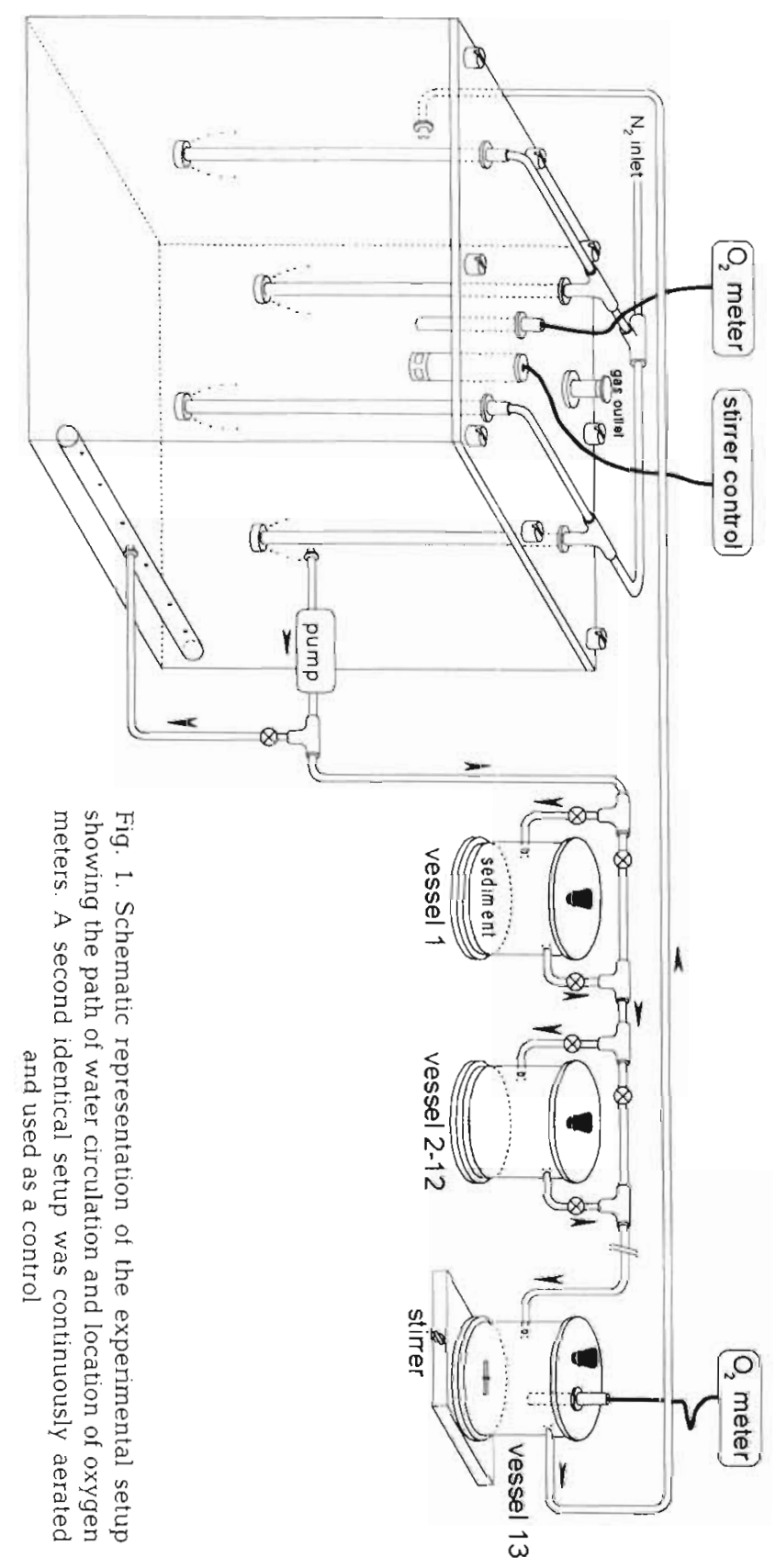

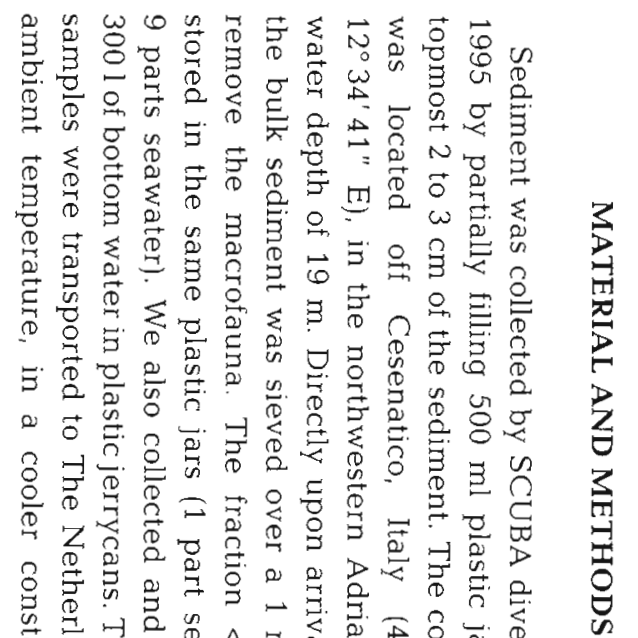

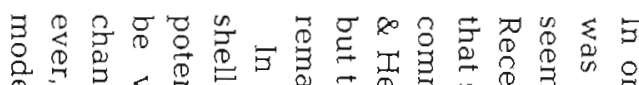

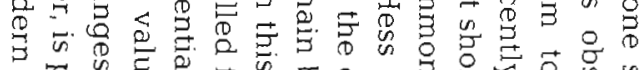

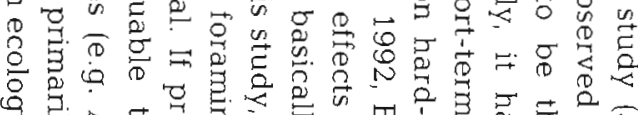

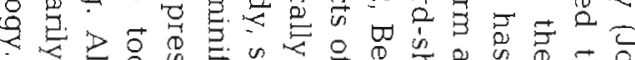

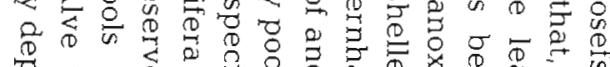

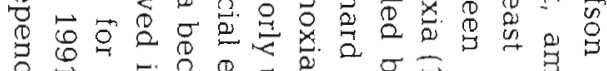

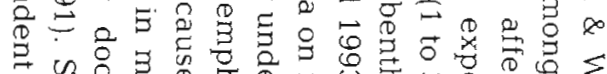

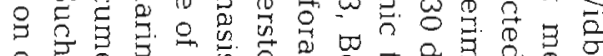

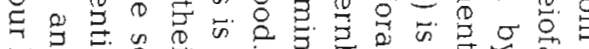

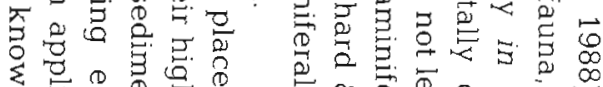

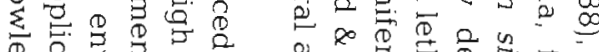

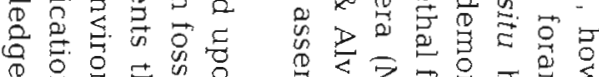

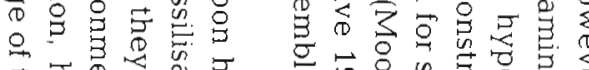

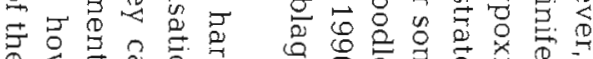

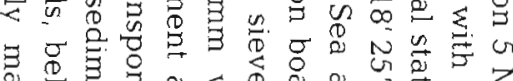

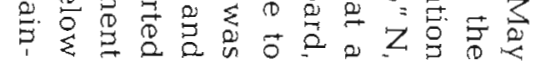

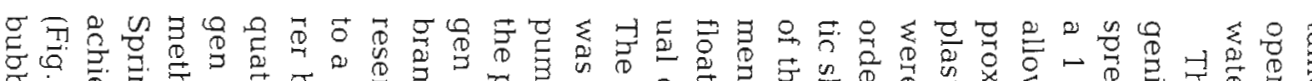

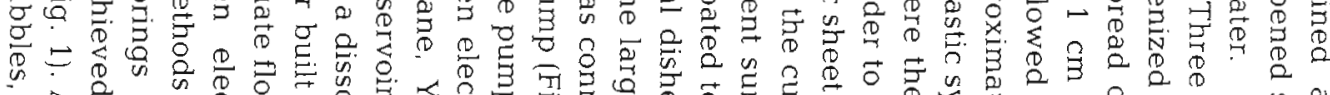

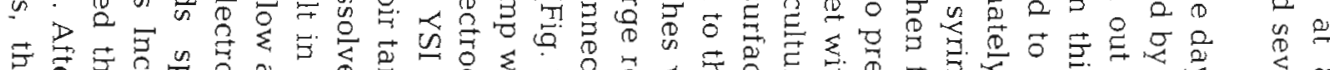

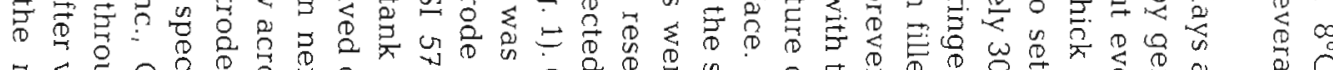

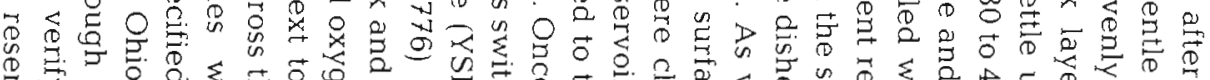

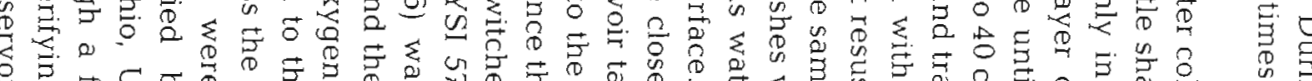

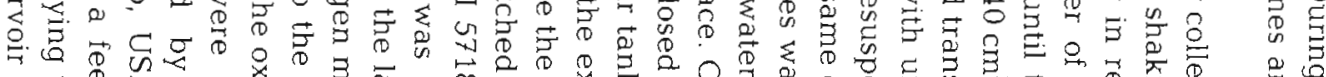

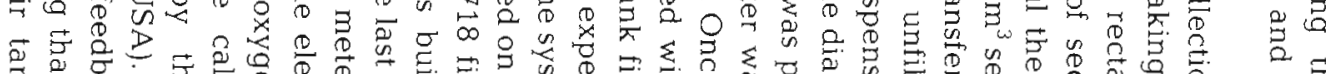

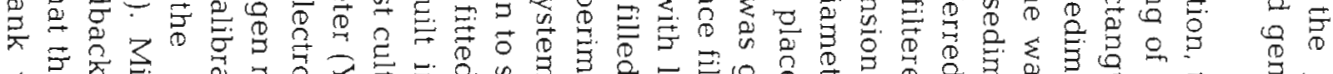

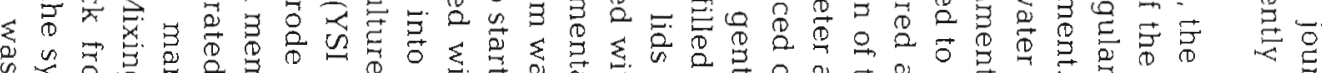

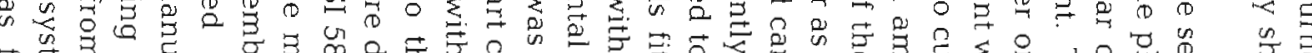

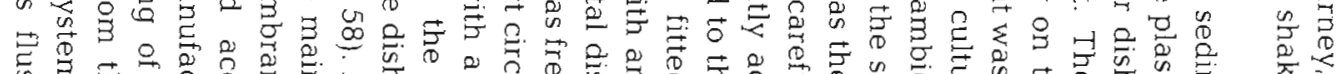

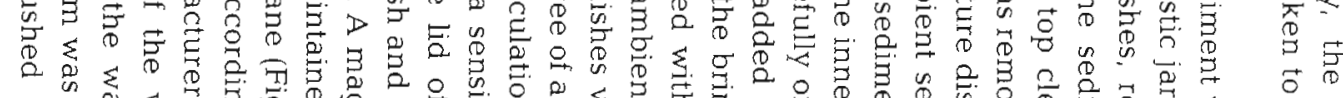

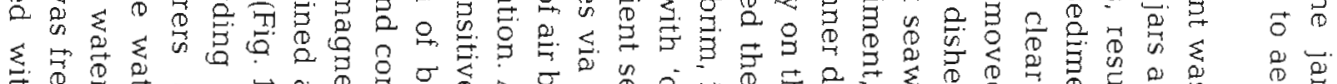

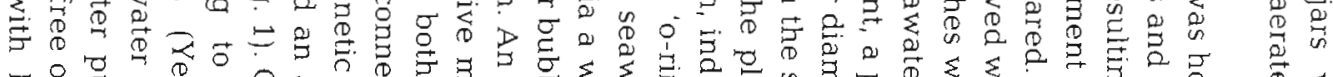

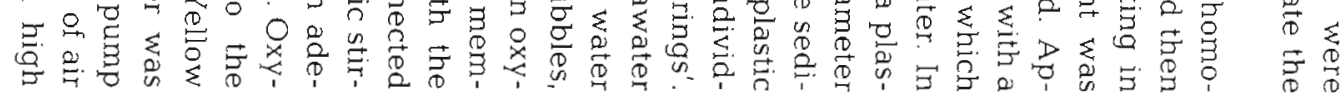


quality nitrogen $\left(\mathrm{N}_{2}\right.$, type 6, i.e. $\left.99.9999 \% \mathrm{~N}_{2}\right)$. When the oxygen concentration dropped to zero both in the reservoir tank and in the last culture dish, the nitrogen supply was discontinued and the system hermetically sealed off (all connections and openings were fitted with 'o-rings'). The resulting setup (Fig. 1) was that oxygen-free water was being circulated continuously throughout the system [which consisted of 1 large water reservoir $(64 \mathrm{l})$ and 13 culture dishes $(10 \mathrm{~cm}$ inner diameter and $542 \mathrm{ml}$ volume)]. The large volume reservoir and the continuous circulation were needed to avoid stagnation and accumulation of toxic products that can form under anoxic conditions. The height and direction of inflow was designed in such a way that it did not cause resuspension of the sediment. Therefore, a carry-over of meiofauna was prevented. The thirteenth dish was not innoculated with sediment but used to monitor the oxygen concentration in the water that passed through all of the other dishes. The oxygen content was monitored throughout the experiment (total of $78 \mathrm{~d}$ ). The experiment was conducted in the dark and maintained at ambient temperature (13.3 \pm $0.2^{\circ} \mathrm{C}$ ) and salinity. No food, beyond that already present in the sediment, was added. A setup similar to that described above was constantly aerated with air and functioned as control (oxic conditions, $234 \pm 6 \mu \mathrm{M}$ or $5.3 \pm 0.1 \mathrm{ml} \mathrm{O}_{2} \mathrm{l}^{-1}$ ).

For each sampling event ( 6 in total), 2 culture dishes were disconnected from each system; due to the bypass this could be achieved without affecting the oxygen concentration in the remainder of the system (Fig. 1). Before it was split into 4 equal parts, the height of the compacted sediment was determined, in order to calculate the exact volume of sediment in each dish. One quarter was removed with a syringe and preserved in $4 \%$ buffered formalin with Rose Bengal; this served for later enumeration and identification of the meiofauna. As a verification of the staining method used to distinguish living specimens from the dead, a second quarter of the total sample was used for a 'lifecheck', i.e. this split was examined immediately for living, motile specimens of the various taxa. Juvenile macrofauna and the permanent metazoan meiofauna were very motile and were readily recognized as living. This check was much more time consuming for foraminifera, however, as they were often encysted in fine particles and resembled faecal pellets. Individual foraminiferal specimens of various species were examined under the inverted microscope for cytoplasmic streaming, used here as the criterion for being alive. This qualitatively verified the Rose Bengal staining results (Goldstein 1988a, Moodley 1990, Goldstein et al. 1995). Additionally, from the anoxic treatment a few living specimens of nematodes and soft-shelled and hard-shelled foraminifera were examined for symbi- otic methanogenic bacteria using epifluorescence microscopy (e.g. Van Bruggen et al. 1983).

It can be argued that the 2 replicate dishes per treatment and per sampling occasion do not constitute true replications of the experimental (oxic or anoxic) treatment. From a practical point of view, however, it was impossible to achieve replication at this level. Not only would a double set of each (oxic and anoxic) setup be needed, but the amount of work in sampling and sorting would also be doubled. Indeed, from experience one expects most variability to occur between the replicate dishes within a treatment, necessitating replication at this level whatever the treatment replication is. Given our time and money constraints, we therefore restricted replication to that level where we expected the highest variability.

The thickness of the compacted sediment layers in the culture vessels varied between 3 and $6 \mathrm{~mm}$ and the total volume of the sample used for faunal studies varied between 9 and $12 \mathrm{~cm}^{3}$. The stained sample was wet-sieved with tap water over a $38 \mu \mathrm{m}$ sieve, and the total residue was examined for stained fauna $\mathrm{ml}$ by $\mathrm{ml}$ after suspension of the sample in water. To facilitate density comparisons, results were normalized to a standard volume of $10 \mathrm{~cm}^{3}$ of sediment. In order to establish whether the trend seen in the hard-shelled foraminiferal assemblage retained on a $38 \mu \mathrm{m}$ sieve was also evident in the fraction more generally used in foraminiferal studies (i.e. specimens retained on a $63 \mu \mathrm{m}$ sieve), the sample was then wet-sieved over a $63 \mu \mathrm{m}$ sieve and the residue re-analysed.

This study addressed (1) the permanent meiofauna, identified to major taxon level and (2) the hard-shelled foraminifera, identified to genus or species level (according to Barmawidjaja et al. 1992). Diversity of the foraminiferal assemblages was estimated using the reciprocal of the proportional abundance of the most common genera (Berger \& Parker 1970, Hill 1973), so that an increase in value of the index indicates an increase in diversity and a reduction in dominance. Softshelled foraminifera (allogromiids and soft-shelled saccamminids) are forms that have a soft, flexible wall and have been described from shallow water environments (e.g. Nyholm 1952, 1953, 1954, 1955a, b, 1974, Nyholm \& Gertz 1973, Goldstein 1988b, Goldstein \& Barker 1988) and the deep sea (e.g. Gooday 1986). Identification of this group was based on the descriptions given in the abovementioned papers and verified by checking for granuloreticulate pseudopodia that branch and anastomose, features characteristic of foraminfera (Travis \& Bowser 1991). Faunal counts were done using a stereomicroscope; the taxonomy of small specimens of hard-shelled foraminifera were verified using a Scanning Electron Microscope. When in doubt, specimens were tallied as unidentified. 
Table 1. Results of the 'life-checks' and sediment parameters. Redox, pH and sulfide were measured using microelectrodes and a calomel reference electrode. Sulfide was not detected by the electrode (lower limit $10 \mu \mathrm{mol} \mathrm{I}^{-1}$ ) but by smell. BW: bottom water; nm: not measured

\begin{tabular}{|c|c|c|c|c|c|c|c|c|c|}
\hline \multirow[t]{2}{*}{ Day } & \multirow[t]{2}{*}{ Treatment } & \multirow{2}{*}{$\begin{array}{l}\text { Juvenile } \\
\text { macrofauna }\end{array}$} & \multicolumn{3}{|c|}{ Permanent meiofauna } & \multirow{2}{*}{$\begin{array}{l}\text { Redox } \\
(\mathrm{mV})\end{array}$} & \multirow[t]{2}{*}{$\mathrm{pH}$} & \multirow[t]{2}{*}{ Sulfide } & \multirow{2}{*}{$\begin{array}{c}\text { BW Oxyger } \\
(\mu \mathrm{M})\end{array}$} \\
\hline & & & Copepods & Nematodes & Foram. & & & & \\
\hline \multirow[t]{2}{*}{1} & Oxic & + & + & + & + & $\mathrm{nm}$ & $\mathrm{nm}$ & - & 227 \\
\hline & Anoxic & + & + & + & + & $\mathrm{nm}$ & $\mathrm{nm}$ & - & 0.00 \\
\hline \multirow[t]{2}{*}{11} & Oxic & + & + & + & + & $\mathrm{nm}$ & $\mathrm{nm}$ & - & $\mathrm{nm}^{\mathrm{d}}$ \\
\hline & Anoxic & - & - & + & + & $\mathrm{nm}$ & $\mathrm{nm}$ & - & 0.00 \\
\hline \multirow[t]{2}{*}{33} & Oxic & + & + & + & + & 295 & 8.06 & - & 237 \\
\hline & Anoxic & - & - & + & + & 1 & 7.97 & - & 0.00 \\
\hline \multirow[t]{2}{*}{53} & Oxic & + & + & + & + & 274 & 7.95 & - & 240 \\
\hline & Anoxic & - & - & + & + & -87 & 7.76 & + & 0.00 \\
\hline \multirow[t]{2}{*}{61} & Oxic & + & + & + & + & 248 & 8.12 & - & $\mathrm{nm}^{\circ}$ \\
\hline & Anoxic & - & - & + & + & -97 & 7.82 & + & 0.00 \\
\hline \multirow[t]{2}{*}{78} & Oxic & + & + & + & + & $\mathrm{nm}$ & $\mathrm{nm}$ & - & $\mathrm{nm}^{\mathrm{a}}$ \\
\hline & Anoxic & - & - & + & + & $\mathrm{nm}$ & $\mathrm{nm}$ & + & 0.00 \\
\hline
\end{tabular}

All counts were $\ln (x+1)$ transformed before statistical analysis by 2 -way analysis of variance (ANOVA) using the MGLH module of SYSTAT (Systat Inc.).

\section{RESULTS}

Upon the initial flushing with nitrogen, sediments in the anoxic series turned from yellowish brown to grey with a few black spots that increased in number with incubation time. After the third sampling event (33 d), the water turned black. The anoxic and eventually reduced conditions were further indicated by the negative redox potential of the sediment and the smell of sulfide (Table 1). In contrast, under oxic conditions the sediment remained yellowish brown.

Although large macrofauna were excluded in our experiments through our use of the $<1 \mathrm{~mm}$ sediment fraction, a few juvenile specimens (bivalves, gastropods or polychaetes) passed through the $1 \mathrm{~mm}$ sieve. At sampling event 1, an average of 42 ind. per $10 \mathrm{~cm}^{3}$ and 12 ind. per $10 \mathrm{~cm}^{3}$ were encountered, respectively, in the oxic and anoxic vessels. Under anoxic conditions, this value dropped to zero after $11 \mathrm{~d}$. Under oxic conditions, this value was reduced to 11 ind. per $10 \mathrm{~cm}^{3}$ after $11 \mathrm{~d}$, and then an average of 1 ind. per $10 \mathrm{~cm}^{3}$ for the remaining sampling events.

Under oxic conditions, all members of the permanent meiofauna and juvenile macrofauna were observed to be living during the 'life-check' at every sampling event (i.e. after $1,11,33,53,61$, and $78 \mathrm{~d}$ of incubation). However, after $78 \mathrm{~d}$ of anoxic conditions, this was the case only for nematodes and foraminifera (both soft and hard shelled; Table 1). No methanogenic bacteria were detected in any of the nematodes or foraminifera examined.

\section{Community response}

Based on the counts of Rose Bengal stained specimens retained on a $38 \mu \mathrm{m}$ sieve, copepods, nematodes and foraminifera together formed more than $96 \%$ of the living permanent meiobenthic community at the beginning of the experiment. The foraminiferal assemblages consisted of both soft-shelled and hard-shelled species.

Among these dominant taxa, copepods appeared to be most sensitive to anoxia; no living specimens were found after the first sampling event (Table 2 , Fig. 2). The densities of both nematodes and softshelled foraminifera decreased faster under anoxic conditions (significant interaction, see Table $2_{1}$ Fig. 2). In contrast, there was no significant difference in total hard-shelled foraminiferal densities between treatments ( $p=0.073$; Table 2, Fig. 2$)$ nor in their relation with time ( $p=0.059$; Table 2$)$. This differential response resulted in a change in the meiobenthic community structure which was already apparent after 1 mo (Fig. 3), with foraminifera, especially hard-shelled foraminifera, becoming the dominant component. The change can be followed in the soft-shelled foraminifera:nematode ratio and even more noticeably in the hard-shelled foraminifera: nematode ratio (Fig. 4) 

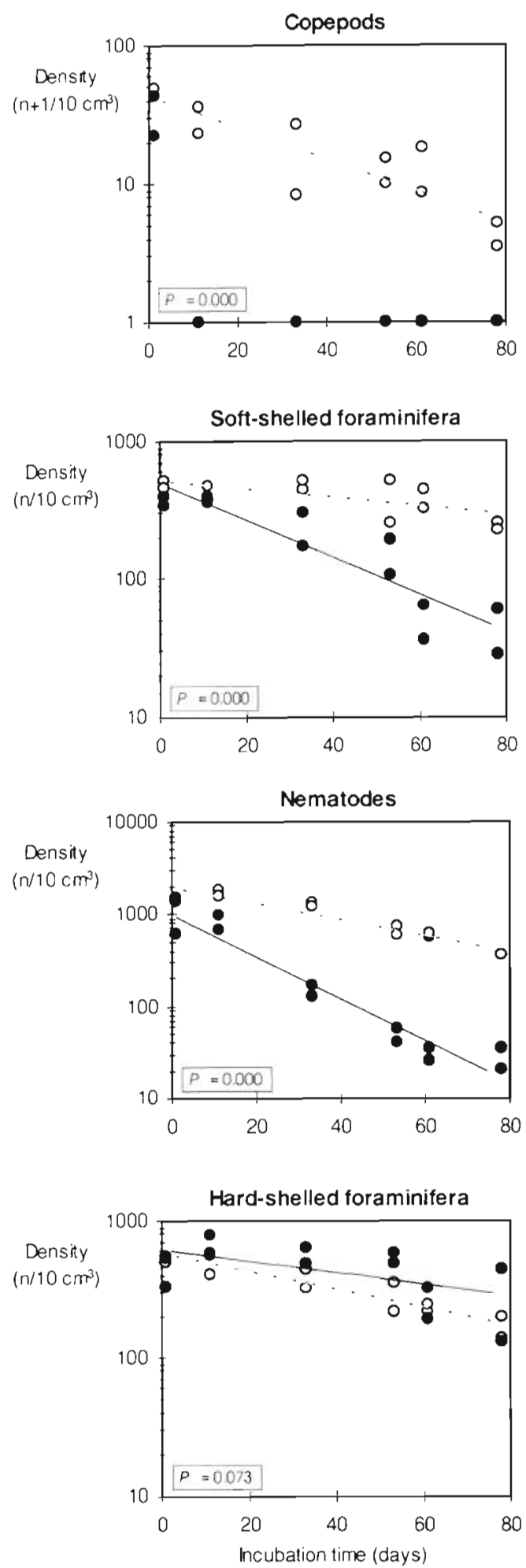

Fig. 2. Densities of dominant meiobenthic taxa retained on a $38 \mu \mathrm{m}$ sieve from the oxic $(0$, dashed line) and the anoxic ( solid line) treatments. $\mathrm{p}$ is the significance of the difference between treatments as indicated by 2-way ANOVA (see Table 2). Note that copepod densities were 0 after Day 1 under anoxic conditions; to show the data $(\mathrm{n}+1) / 10 \mathrm{~cm}^{3}$ is plotted

\section{Hard-shelled foraminifera}

Initially, calcareous species formed the majority of the assemblage $(\sim 80 \%$ hyaline and $\sim 5 \%$ porcellaneous) with agglutinated species accounting for the remaining $15 \%$. Due to the difficulty of identifying some very small individuals to species level and the scarcity

Table 2. Two-way ANOVA of the densities of dominant meiobenthic taxa and various dominant genera of hard-shelled foraminifera retained on a $38 \mu \mathrm{m}$ sieve

\begin{tabular}{|c|c|c|c|c|c|}
\hline Source & df & SS & MS & F-ratio & $\mathrm{p}$ \\
\hline \multicolumn{6}{|l|}{ Copepods } \\
\hline Time & 5 & 20.73 & 4.15 & 34.97 & 0.000 \\
\hline Treatment & 1 & 27.97 & 27.97 & 235.91 & 0.000 \\
\hline Interaction & 5 & 5.55 & 1.11 & 9.37 & 0.001 \\
\hline Error & 12 & 1.42 & 0.12 & & \\
\hline \multicolumn{6}{|l|}{ Nematodes } \\
\hline Time & 5 & 22.74 & 4.55 & 73.67 & 0.000 \\
\hline Treatment & 1 & 21.55 & 21.55 & 349.18 & 0.000 \\
\hline Interaction & 5 & 5.78 & 1.16 & 18.72 & 0.000 \\
\hline Error & 12 & 0.74 & 0.06 & & \\
\hline \multicolumn{6}{|c|}{ Soft-shelled foraminifera } \\
\hline Time & 5 & 7.07 & 1.41 & 15.09 & 0.000 \\
\hline Treatment & 1 & 5.70 & 5.70 & 60.85 & 0.000 \\
\hline Interaction & 5 & 2.99 & 0.60 & 6.38 & 0.004 \\
\hline Error & 12 & 1.12 & 0.09 & & \\
\hline \multicolumn{6}{|c|}{ Hard-shelled foraminifera } \\
\hline Time & 5 & 3.43 & 0.69 & 5.92 & 0.006 \\
\hline Treatment & 1 & 0.45 & 0.45 & 3.87 & 0.073 \\
\hline Interaction & 5 & 0.44 & 0.089 & 0.768 & 0.590 \\
\hline Error & 12 & 1.39 & 0.12 & & \\
\hline \multicolumn{6}{|l|}{ Nonionella } \\
\hline Time & 5 & 4.93 & 0.99 & 13.34 & 0.000 \\
\hline Treatment & 1 & 8.17 & 8.17 & 110.54 & 0.000 \\
\hline Interaction & 5 & 1.80 & 0.360 & 4.88 & 0.011 \\
\hline Error & 12 & 0.89 & 0.07 & & \\
\hline \multicolumn{6}{|l|}{ Stainforthia } \\
\hline Time & 5 & 2.51 & 0.501 & 2.176 & 0.125 \\
\hline Treatment & 1 & 3.76 & 3.76 & 16.32 & 0.002 \\
\hline Interaction & 5 & 2.29 & 0.458 & 1.99 & 0.152 \\
\hline Error & 12 & 2.76 & 0.23 & & \\
\hline \multicolumn{6}{|l|}{ Reophax } \\
\hline Time & 5 & 8.96 & 1.79 & 13.80 & 0.000 \\
\hline Treatment & 1 & 0.83 & 0.83 & 6.401 & 0.026 \\
\hline Interaction & 5 & 0.903 & 0.181 & 1.391 & 0.295 \\
\hline Error & 12 & 1.56 & 0.13 & & \\
\hline \multicolumn{6}{|l|}{ Bolivina } \\
\hline Time & 5 & 5.03 & 1.01 & 6.36 & 0.004 \\
\hline Treatment & 1 & 0.536 & 0.536 & 3.388 & 0.091 \\
\hline Interaction & 5 & 1.061 & 0.212 & 1.34 & 0.312 \\
\hline Error & 12 & 1.90 & 0.16 & & \\
\hline \multicolumn{6}{|l|}{ Hopkinsina } \\
\hline Time & 5 & 2.09 & 0.42 & 0.716 & 0.624 \\
\hline Treatment & 1 & 0.04 & 0.04 & 0.067 & 0.799 \\
\hline Interaction & 5 & 0.95 & 0.19 & 0.323 & 0.890 \\
\hline Error & 12 & 7.02 & 0.59 & & \\
\hline
\end{tabular}


(a)

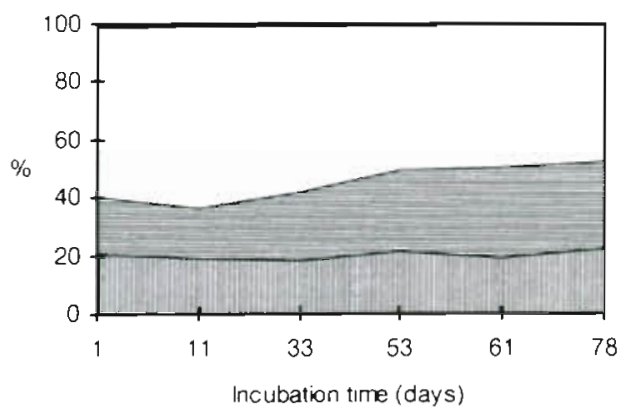

Copepods $\square$ Nematodes (b)

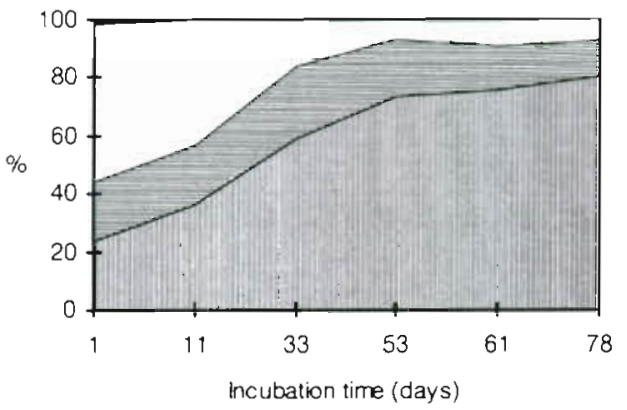

Sott-shelled foraminifera Hard-shelled foraminifera

Fig. 3. Relative abundance (average percentage) of the dominant permanent meiobenthic taxa vs incubation time for (a) oxic and (b) anoxic conditions

Soft-shelled foraminifera/nematode ratio

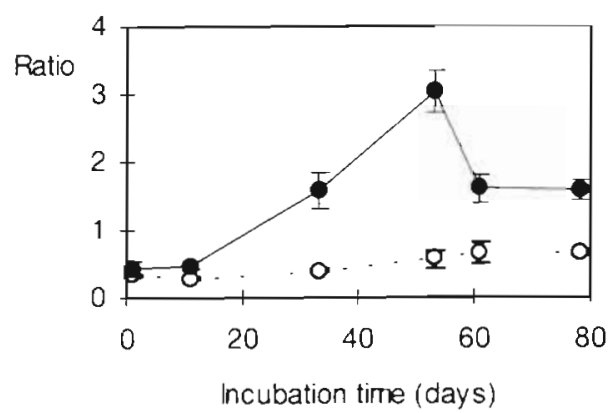

Hard-shelled foraminifera/nematode ratio

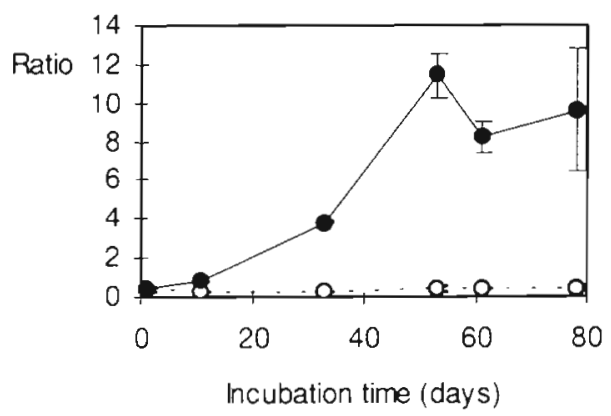

Fig. 4. Shift in the foraminifera:nematode ratio (mean $\pm S D$ ) with incubation time in the oxic (O) and anoxic treatments

of data, analysis of the data was performed at the generic level. Five genera formed more than $5 \%$ of the assemblage in all 6 sampling events in both the oxic and anoxic treatments. Nonionella (predominantly $N$. turgida), Stainforthia (predominantly $S$. fusiformis), Bolivina (predominantly $B$. dilatata with $B$. seminuda and $B$. spathulata) and Hopkinsina (predominantly $H$. pacifica) were the 4 dominant calcareous genera and Reophax ( $R$. scottii and $R$. nana) was the only dominant agglutinated genus. Other genera were too rare for statistical analysis. Additional genera that were found living after the anoxic treatment include Quinqueloculina, Buliminella, Ammonia, Bulimina, Epistominella, Eggerella, Ammoscalaria, and Cribrostomoides.

Of the 5 dominant genera, densities of Nonionella and Stainforthia were significantly higher under anoxic conditions $(p<0.01)$, Reophax densities were slightly lower ( $\mathrm{p}=0.026$ ) and densities of Bolivina and Hopkinsina were not affected ( $p>0.05$; Table 2, Fig. 5).

The number of hard-shelled foraminifera retained on a $63 \mu \mathrm{m}$ sieve was strikingly low and ranged from 24 to
86 ind. per $10 \mathrm{~cm}^{3}$ (Fig. 6), whereas the number of specimens $>38 \mu \mathrm{m}$ ranged from 68 to 685 ind. per $10 \mathrm{~cm}^{3}$ (Fig. 2). The fraction retained on a $63 \mu \mathrm{m}$ sieve was on average less than $20 \%$ of the total retained on a $38 \mu \mathrm{m}$ sieve. Density values in the $63 \mu \mathrm{m}$ fraction, as a whole, reflect the general high resistance of the hardshelled foraminifera to anoxia (Fig. 6). This coarser fraction may, however, bias the results towards some genera. For example, the relative proportion of genera with elongate morphology (Stainforthia, Bolivina, Reophax and to a lesser extent Hopkinsina) is reduced in the $63 \mu \mathrm{m}$ fraction, leading to an overestimation of the dominance of Nonionella (a more ovate foram) under both oxic and anoxic conditions (Fig. $7 \mathrm{a}, \mathrm{b}$ ). This sieving artifact is clearly reflected in the generic diversity trends (Fig. 8a, b). Generic diversity of the coarser fraction increases with time under oxic conditions $\left(\mathrm{r}^{2}=\right.$ $0.620, p=0.00$ ) but remains relatively constant under anoxic conditions $\left(\mathrm{r}^{2}=0.336, \mathrm{p}=0.05\right)$. However, in the $38 \mu \mathrm{m}$ fraction diversity is much higher and does not change significantly with time under oxic conditions 

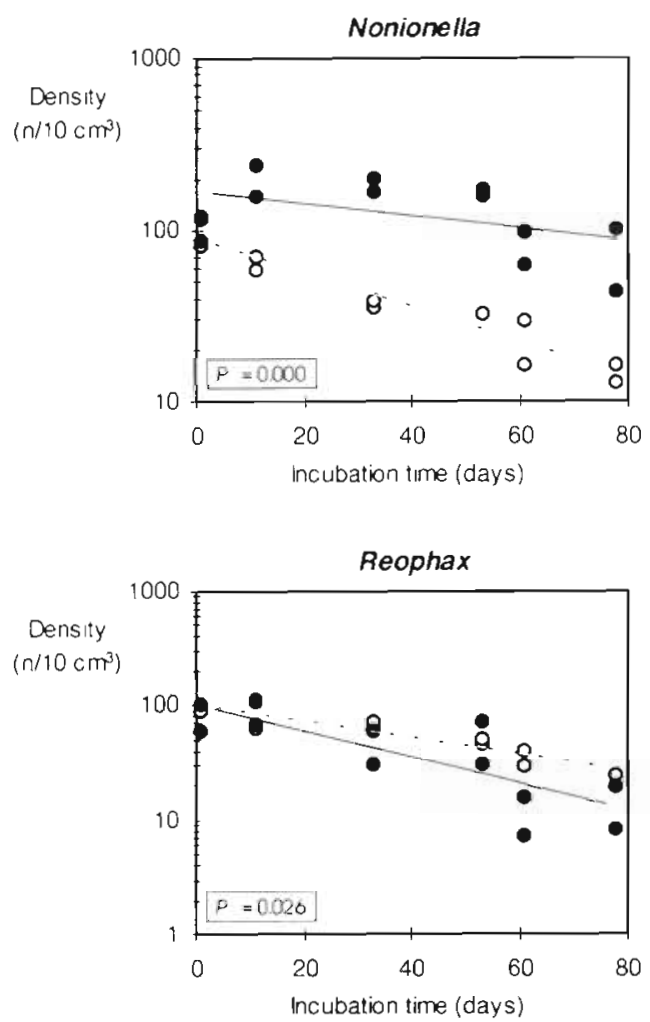

Fig. 5. Densities of dominant hard-shelled foraminiferal genera retained on a $38 \mu \mathrm{m}$ sieve from the oxic $(0$, dashed line) and anoxic ( solid line) treatments $\mathrm{p}$ is the significance of the difference between treatments as indicated by 2-way ANOVA (see Table 2)

$\left(\mathrm{r}^{2}=0.003, \mathrm{p}=0.86\right)$ but it decreases significantly under anoxic conditions $\left(r^{2}=0.652, p=0.00\right.$; Fig. $\left.8 a, b\right)$.

\section{DISCUSSION}

The northern Adriatic Sea is one of the estuarine and shallow marine regions where severe hypoxia $(<0.2 \mathrm{ml}$ $\mathrm{O}_{2} \mathrm{l}^{-1}$ or $<8.8 \mu \mathrm{M} \mathrm{O}_{2}$ ) are observed seasonally (Diaz \& Rosenberg 1995). Our sampling site is within the area that is affected by seasonal bottom-water hypoxia, with values dropping below $1 \mathrm{ml} \mathrm{O}_{2} \mathrm{l}^{-1}\left(44 \mu \mathrm{M} \mathrm{O}_{2}\right)$ during late summer (Regione Emilia-Romagna 1993). This probably results in severe dysoxic and anoxic conditions for the infauna. Surficial sediment $(0$ to $1 \mathrm{~cm})$ in
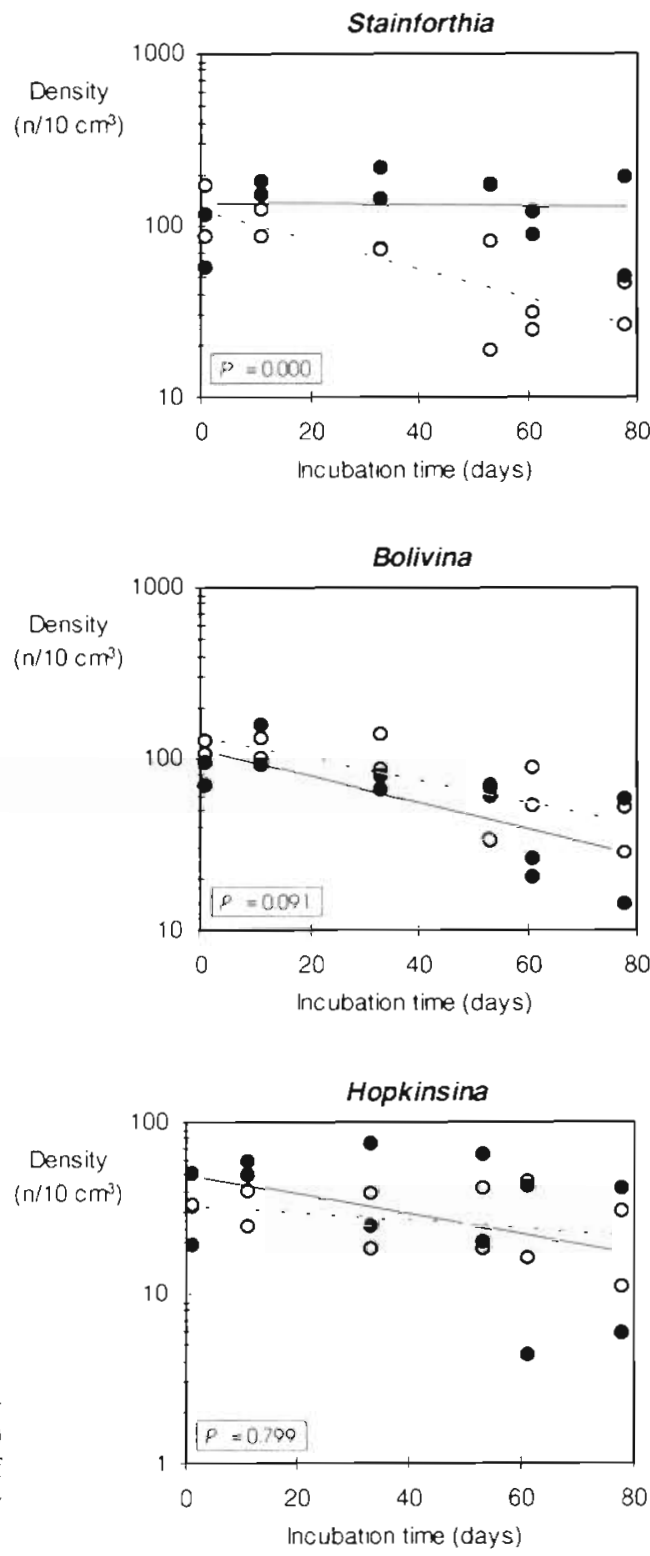

this area consists of muddy silt sediment (median grain size: $11 \mu \mathrm{m}, 96 \%$ mud) with a relatively high organic carbon content. In May 1995 the upper $5 \mathrm{~mm}$ of the sediment contained $1.02 \%$ organic carbon (Moodley et al. in press a). Oxygen is rapidly consumed in the sediment surface layers and has a maximum penetration depth of about $7 \mathrm{~mm}$ in winter, dropping to less than $2 \mathrm{~mm}$ in May (Moodley et al. in press a). The meiofauna in this area is therefore expected to be adapted to low oxygen levels. The oxygen penetration depth in the sediment layers of the oxic treatment is of critical importance for the experiment discussed in this paper. This was estimated with a microelectrode on Day 53 to be $220 \mathrm{MMO}_{2}\left(-5 \mathrm{ml} \mathrm{O}_{2} \mathrm{l}^{-1}\right)$ at the sediment surface and $215 \mu \mathrm{M} \mathrm{O}_{2}$ at $\sim 0.2 \mathrm{~mm}$ below the sediment-water inter- 

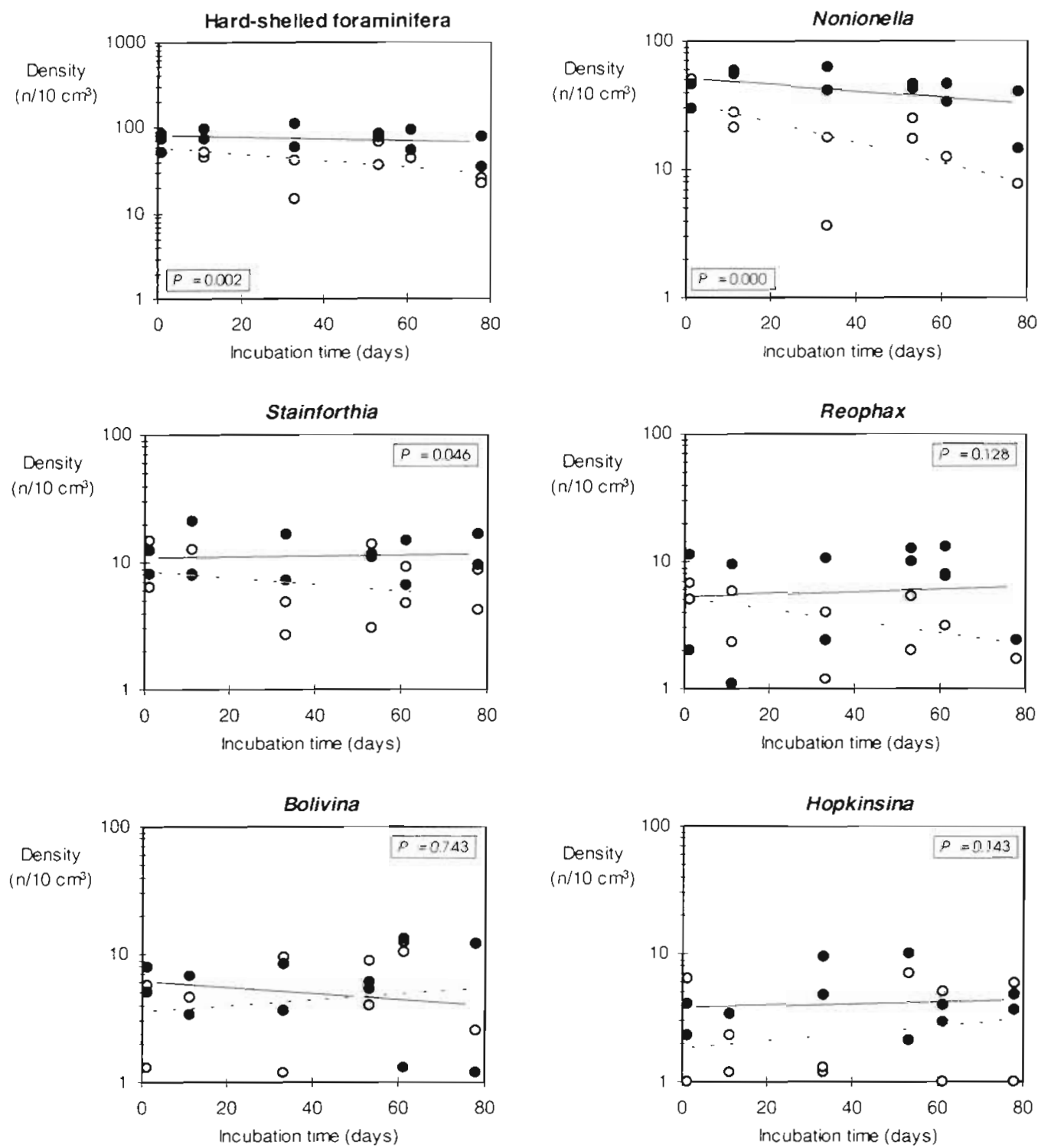

Fig. 6. Total hard-shelled foraminiferal densities and densities of dominant genera retained on a $63 \mu \mathrm{m}$ sieve in the oxic $(0$, dashed line) and anoxic ( $\bullet$, solid line) treatments. $\mathrm{p}$ is the significance of the difference between oxygen treatments as indicated by 2 -way ANOVA (see Table 2)

face. The oxygen concentration throughout the entire sediment layer was not measured, but based on other experiments showing oxygen penetration to $-5 \mathrm{~mm}$ (Moodley et al. in press b), it is realistic to assume that free oxygen was present in the bulk of the thin layers of sediment ( 3 to $6 \mathrm{~mm}$ ) used in this study. However, a penetration depth of $5 \mathrm{~mm}$ is still substantially deeper than that measured in untreated field cores (less than $2 \mathrm{~mm}$ under bottom-water oxygen contents of $175 \mu \mathrm{M}$ $\mathrm{O}_{2}$ or $4 \mathrm{ml} \mathrm{O}_{2} \mathrm{I}^{-1}$ ). This is probably related to the experimental treatment, as the sediment fraction smaller than $1 \mathrm{~mm}$ (i.e. excluding large macrofauna) of the upper sediment layers $(3$ to $5 \mathrm{~cm}$ ) was first mixed and then maintained in water with a higher oxygen content of $234 \pm 6 \mu \mathrm{M} \mathrm{O}_{2}\left(-5.3 \pm 0.1 \mathrm{ml} \mathrm{O}_{2} \mathrm{l}^{-1}\right)$. Additionally, and probably more importantly, oxygen consumption as a result of re-oxidation of reduced compounds diffusing up from deep sediment layers is excluded when using a thin layer of sediment. For typical shelf sediments, a large part of the oxygen uptake is attributed to re-oxidation of, for example, $\mathrm{H}_{2} \mathrm{~S}, \mathrm{FeS}_{\mathrm{x}}$ and $\mathrm{Mn}^{2+}$ (Heip et al. 1995, Soetaert et al. 1996).

As observed during other periods of the year (Moodley et al. in press a), the permanent meiofauna of our study site was dominated by nematodes and foraminifera, with copepods forming only a small part of the 
(a)
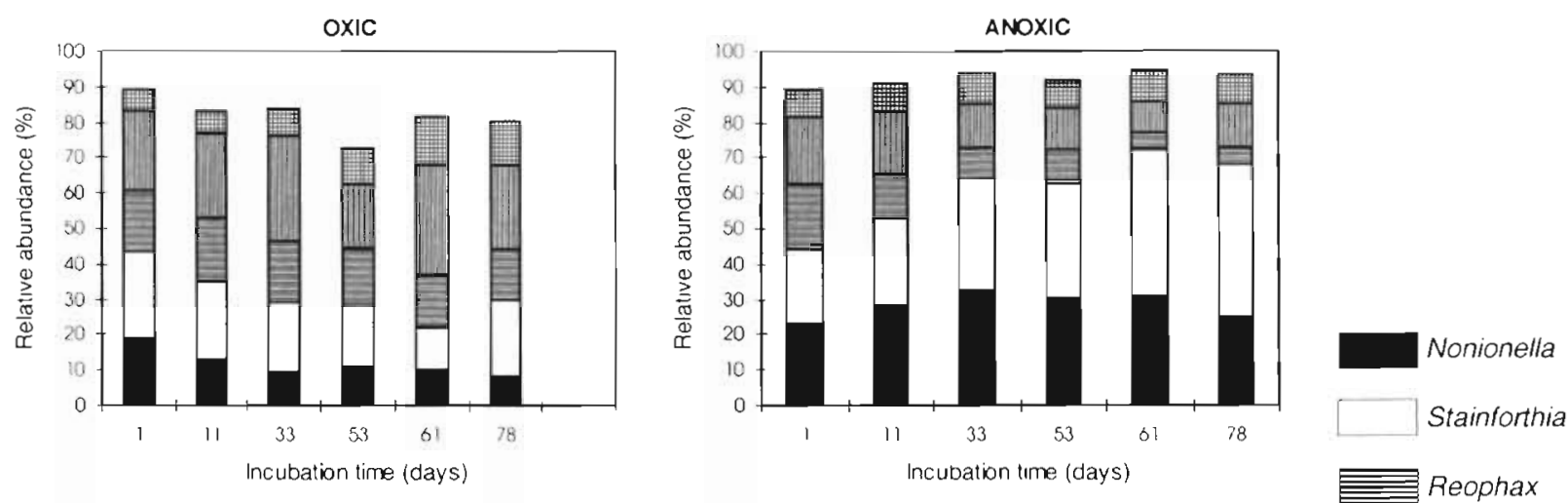

(b)
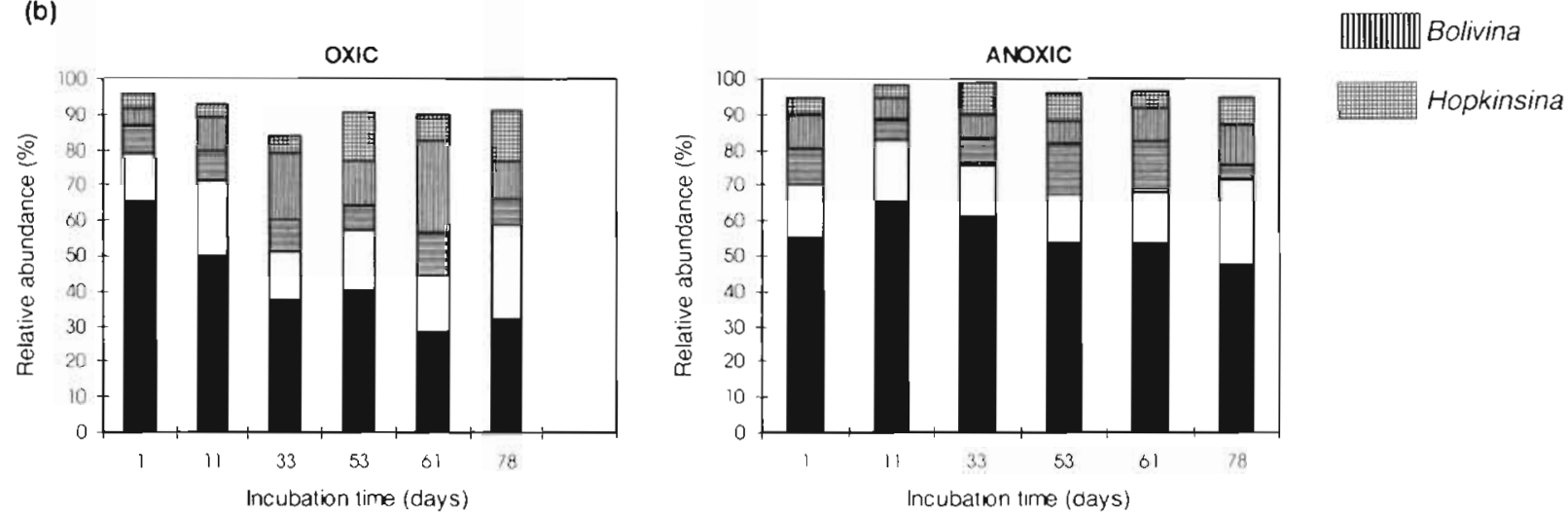

Fig. 7. Contribution of the dominant genera to the total abundance of hard-shelled foraminifera retained on (a) a $38 \mu \mathrm{m}$ sieve and (b) a $63 \mu \mathrm{m}$ sieve for the 2 treatments

(a)

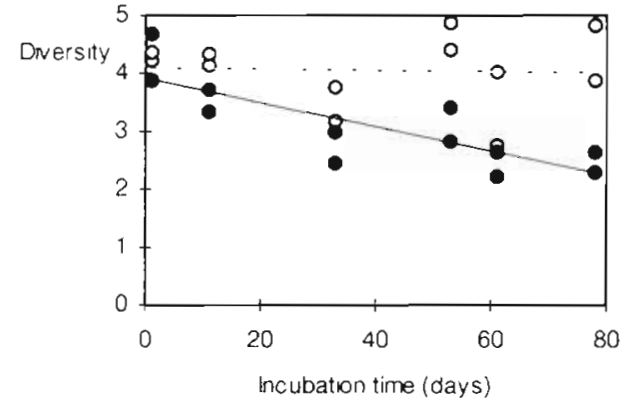

(b)

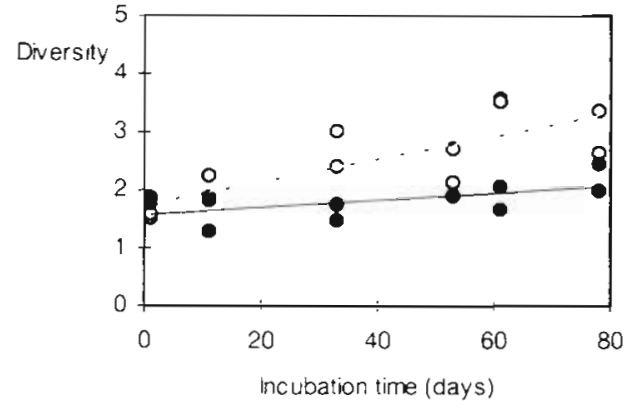

Fig. 8. Generic diversity of the hard-shelled foraminiferal assemblage retained on (a) a $38 \mu \mathrm{m}$ sieve and (b) a $63 \mu \mathrm{m}$ sieve for the oxic $(0$, dashed line) and anoxic $(\bullet$, solid line) treatments

community. Earlier studies of the metazoan meiofauna in the Adriatic also confirm the relatively minor importance of other taxa and the strong dominance of nematodes (Vidakovic 1984).

In our study, copepods were the group most sensitive to anoxic conditions, in accordance with earlier observations. Meiofaunal crustaceans, which are highly motile and normally occur in well-oxygenated envi- ronments, generally appear to be highly sensitive to hypoxic conditions (e.g. Coull 1969, de Bovee 1975, Elmgren 1975, Heip 1980, Josefson \& Widbom 1988, Levin et al. 1991, Diaz \& Rosenberg 1995). The less motile, infaunal components are expected to be more tolerant to low oxygen levels (Josefson \& Widbom 1988). Within the metazoan meiofauna, nematodes, which normally are numerically dominant in subtidal 
soft bottom communities, generally exhibit a high tolerance to oxygen deficiency (e.g. Elmgren 1975). Several species are able to withstand anoxic conditions for at least $60 \mathrm{~d}$ (Wieser \& Kanwisher 1961). In our study, both the nematodes and foraminifera (soft and hard shelled) were able to withstand anoxic conditions for at least $78 \mathrm{~d}$. However, densities of nematodes and softshelled foraminifera were significantly reduced under prolonged anoxia whereas total hard-shelled foraminiferal densities were not affected. This differential response creates the possibility of utilizing ratios of these major taxa as indicators of prolonged anoxia. However, it should be noted that this may not be applicable to all coastal areas as our samples were taken from an area where severe oxygen depletion is commonly observed. Adaptation of certain taxa to these conditions cannot be excluded. To test this possibility, similar experiments are required with meiofauna from areas where hypoxic/anoxic conditions do not occur

Commonly, metazoan meiofauna and soft-shelled foraminifera are extracted from the sediment by centrifugation with Ludox (Heip et al. 1985). However, with this procedure, most hard-shelled foraminifera remain in the sediment (e.g. Moodley et al. in press a). Therefore, the use of the hard-shelled foraminifera: nematode ratio, which is probably a better indicator of prolonged anoxia than the soft-shelled foraminifera: nematode ratio, would require that the residual sediment also be examined.

\section{Hard-shelled foraminifera}

In this study area, the proportion of the assemblage retained on a $63 \mu \mathrm{m}$ sieve was strikingly low (on average less than $20 \%$ of total retained on a $38 \mu \mathrm{m}$ sieve). This implies that the assemblages consisted either mainly of juveniles or of small-sized individuals. A study of the dead assemblage in the surface sediment layers in the field (i.e. foraminifera produced over a period of $\sim 3 \mathrm{yr}$ ) revealed a similar proportion of size classes (Van Neuren 1996) and indicates that this area is characterized by small individuals, that are not retained on a $63 \mu \mathrm{m}$ sieve. Unidentifiable infants (2 to 4 chambered specimens) were not abundant (a maximum of 14 specimens per $10 \mathrm{~cm}^{3}$ sediment) and were encountered at the first 2 sampling events of the anoxic treatment and in all except the last 2 sampling events in the oxic treatment.

Many studies of modern benthic foraminifera have focussed on sieve fractions larger than $125 \mu \mathrm{m}$ (Douglas \& Woodruff 1981). However, it has been demonstrated that this could lead to erroneous conclusions and a workable, pragmatic lower limit of $63 \mu \mathrm{m}$ was recommended (Schröder et al. 1987, Sen Gupta at al. 1987). The choice of $63 \mu \mathrm{m}$ would eliminate all clay and silt while retaining almost all foraminifera and sand. A comparison with smaller sieves was not made, but if one wishes to retain the entire population, including a number of unidentifiable juveniles, a sieve of about $20 \mu \mathrm{m}$ has to be employed (Schröder et al. 1987). Our study site is evidently characterized by small individuals of which only a small portion is retained on a $63 \mu \mathrm{m}$ sieve. Bernhard \& Reimers (1991) suggested that under favorable conditions, e.g. abundant food or diminished biological interactions, foraminiferal populations are characterized by small individuals, as a result of rapid reproduction. Similar conditions could indeed prevail in eutrophic coastal areas as the northwestern Adriatic Sea. From a paleoecological point of view, the relative proportion of the various genera or species forms an important source of information. As demonstrated in this study, significantly different trends are seen depending on whether a $38 \mu \mathrm{m}$ or a $63 \mu \mathrm{m}$ sieve is used (Figs. $7 \mathrm{a}, \mathrm{b} \& 8 \mathrm{a}, \mathrm{b}$ ). The use of sieves with a smaller opening (e.g. 38 or $45 \mu \mathrm{m}$ ) may be necessary in certain areas, especially for detailed ecological studies, but this introduces a new set of problems. Identification of extremely small individuals to species level is very time-consuming and may be problematic, although genera are readily recognized.

Because all of the hard-shelled foraminifera species survived prolonged anoxia (78 d), our results support the assertion that many benthic foraminifera are facultative anaerobes (Moodley \& Hess 1992, Bernhard 1993, Bernhard \& Alve 1996). This is to be expected considering their natural habitat. Although several divisions have been proposed (e.g. Corliss 1985, Barmawidjaja et al. 1992), the majority of the species inhabiting soft bottoms can be considered as infaunal (Buzas et al. 1993). If one takes into account that they are very slow moving $\left(0.5\right.$ to $30 \mathrm{~mm} \mathrm{~h}^{-1}$; Kitazato 1988 , Wetmore 1988) and cannot provide their own supply of oxygen, as can some macrofauna, a high resistance to anoxia can be expected. Responses to anoxia could include dormancy and anaerobic metabolic pathways (Bernhard \& Alve 1996); however, no association with methanogenic bacteria has been observed (Moodley \& Hess 1992, Bernhard 1996, this study).

Some genera (in this case Nonionella and Stainforthia) seemed to benefit from conditions created by the anoxic treatment, i.e. survival was higher under anoxic than under oxic conditions (Fig. 5). This suggests that biological interactions (e.g. disturbance, competition) might be an important factor limiting these species. A direct preference for anoxic conditions is most unlikely as these species have also been reported to dominate under oxic conditions (Murray 1992, Alve \& Bernhard 
1995, Moodley et al. in press b). This conclusion is supported by the fact that there was no significant change in densities under anoxic conditions for either Nonionella or Stainforthia ( $\mathrm{p}>0.05$ ), suggesting that reproduction did not take place.

Based on distributional studies and studies on the metabolic activity of species exposed to short-term anoxia, Bernhard \& Alve (1996) suggested that Stainforthia and Nonionella are more tolerant to anoxia than other foraminifera. This is supported by the dominance of these 2 genera under anoxic conditions (Fig. 7a) and the fact that both Stainforthia and Nonionella looked distinctly healthier in the 'life-check' compared to, e.g., Reophax. However, it is important to realize that the dominance of both Stainforthia and Nonionella is a result of their higher survival under the conditions created by the anoxic treatment compared to oxic conditions. Of the 5 dominant genera encountered in our study, Reophax was the only genus that seemed negatively affected by the anoxic treatment (Fig. 5). Prolonged anoxia evidently affects foraminifera either directly or indirectly, but the exact mechanism remains unresolved at this stage. We hypothesize that species like Nonionella and Stainforthia will continue to have a competitive edge upon initial re-oxygenation but gradually decrease in dominance with time. Short-term anoxia (shorter than a few weeks) is not expected to cause drastic changes in the composition of the foraminiferal assemblage (Fig. 7a). How ever, faunal tolerance to anoxia in combination with sulfide might be different (Diaz \& Rosenberg 1995), although this does not appear to qualitatively affect some common benthic foraminifera (Bernhard 1993). It was not possible to evaluate independently the effect of sulfide in our study because it could not statistically be separated from the effect of long anoxic incubation. In general, the data suggests that sulfide (present after 53 d) does not change the trends that were already evident before Day 53, except for Reophax, for which a sudden drop is seen after Day 53. An effect of sulfide independent of the effect of anoxia cannot be excluded, but more specific experiments need to be carried out.

Foraminifera are prevalent members of the benthic community (e.g. Ellison 1984, Rudnick et al. 1985, Josefson \& Widbom 1988, Moodley et al. in press a), and in soft sediments the majority occur infaunally (Buzas et al. 1993). They have been encountered living at depths of 30 to $35 \mathrm{~cm}$ (e.g. Goldstein 1988a, Moodley 1990, Moodley \& Hess 1992, Goldstein et al. 1995). The penetration of oxygen in fine-grained sediment is generally very shallow (e.g. Revsbech et al. 1980, Rasmussen \& Jørgensen 1992, Lohse et al. 1995), thus emphasizing the limited direct role of oxygenation in structuring surface and subsurface distribution pat- terns of benthic foraminifera. Among the benthic meiobenthos, foraminifera seem to be least affected by hypoxic conditions ( 1 to $0.21 \mathrm{ml} \mathrm{O}_{2} \mathrm{I}^{-1}$ or 44 to $9.2 \mu \mathrm{M}$ $\mathrm{O}_{2}$; Josefson \& Widbom 1988) and most resistant to anoxic conditions (this study). Based on the sediment surface and subsurface oxygen data reported in some foraminiferal studies (e.g. Bernhard 1989, 1992, Moodley 1990, unpubl. data) and the general oxygenation regime in subsurface sediment layers (e.g. Revsbech et al. 1980, Rasmussen \& Jørgensen 1992, Lohse et al. 1995), it can be concluded that the majority of common benthic foraminifera inhabiting soft sediments are in fact operating at the lower end of the oxic range with substantial portions often inhabiting suboxic/anoxic sediment. This is supported by recent experimental studies that reported growth (Moodley \& Hess 1992) and reproduction (Alve \& Bernhard 1995) under moderate to extreme dysoxic (2 to $0.2 \mathrm{ml} \mathrm{O}_{2} \mathrm{l}^{-1}$ or 88 to $8.8 \mathrm{\mu M} \mathrm{O}_{2}$ ) bottom-water conditions - the oxygen content in the sediment being inevitably lower (see Moodley et al. 1996b), so that the values given represent upper limits. Macrofaunal activity may provide oxygen to deeper sediment layers, but concentrations remain low. Macrofaunal burrows can be considered the largest source of subsurface oxygen but, although relatively higher densities of meiofauna or foraminifera can be found near burrow structures, a larger proportion of the assemblage is found outside the oxic zone (e.g. Aller \& Aller 1986, Meyers et al. 1987, 1988, Thomsen \& Altenbach 1993, Moodley et al. in press b). Additionally, subduction of the surface oxic zone is by no means uniform and the subsurface occurrence of foraminifera below the oxygenated layer is usually not directly associated with burrows. Alve \& Bernhard (1995) reported differential preference levels of oxygen content between species within the dysoxic range (less than $2 \mathrm{ml} \mathrm{O}_{2} \mathrm{l}^{-1}$ or $88 \mu \mathrm{M} \mathrm{O}_{2}$ ). The infaunal species Stainforthia fusiformis only outnumbered the epifaunal species Bulimina marginata when bottom water oxygen concentrations were less than $0.2 \mathrm{ml} \mathrm{O}_{2} \mathrm{I}^{-1}$ or $8.8 \mathrm{\mu M} \mathrm{O}_{2}$ (Alve \& Bernhard 1995). This was supported by subsequent field observations, as $B$. marginata still outnumbered $S$. fusiformis in sediments with bottom waters (10 $\mathrm{cm}$ above the sediment) having an oxygen content of $0.95 \mathrm{ml} \mathrm{O}_{2} \mathrm{l}^{-1}\left(41.5 \mu \mathrm{M} \mathrm{O}_{2}\right)$ in the Drammensfjord, Norway (Bernhard \& Alve 1996), with the oxygen content in the sediment being certainly lower. If differential effects or responses are indeed operating at such low oxygen concentrations and if this is true for other common foraminifera inhabiting soft sediments, the direct impact or role of oxic conditions (i.e. upper end of the oxic range) on foraminifera might be very limited. They are probably best described as microaerophiles which are highly resistent to anoxic conditions. 
As discussed in a recent review of benthic foraminifera in oxygen-poor habitats (Sen Gupta \& MachainCastillo 1993), oxygen conditions in many instances seem to be an obvious parameter for explaining foraminiferal distributional patterns, although the primary influences may stem from other parameters. Overall, benthic foraminiferal species dominant in long-term dysoxic or suboxic habitats are also present, although not necessarily dominant, under well-oxygenated conditions (Sen Gupta \& Machain-Castillo 1993). Assigning levels of tolerance to low oxygen concentrations based solely on the position of foraminifera in the sediment, or general test morphology and/or specific morphological characteristics, is clearly an oversimplification, especially since the majority of foraminifera inhabiting soft sediments appear to be living within the hypoxic range. These foraminifera evidently flourish under low oxygen conditions and have a very high tolerance to anoxia. Therefore, they are probably not eliminated during seasonal anoxia with a duration of 2 to 3 mo. This may explain the relatively rapid recolonization of a 'defaunated' area by these relatively slow moving organisms. However, one would expect that stable long-term anoxia, persisting over for instance 6 mo, would eliminate foraminifera indeed, as there are no reports of foraminifera occurring in permanently anoxic environments.

Acknowledgements. Jack J. Middelburg and Karline Soetaert are gratefully acknowledged for their critical review and valuable suggestions as is Eric Slim for his skillful assistance underwater. Hanneke Schut is thanked for fruitful discussions. Helpful comments from 4 anonymous reviewers improved the manuscript. The technical department of the Nijmegen University constructed the experimental equipment and the Department of Microbiology of the Nijmegen University is thanked for the use of their epifluorescence microsope. This research and L.M. were financially supported by the Netherlands Geosciences Foundation (GOA, grant no. 555-750.194.06 to G.J.Z.). This is publication no. 2289 of the NIOO-CEMO.

\section{LITERATURE CITED}

Aller JY, Aller RC (1986) Evidence for localized enhancement of biological activity associated with tube and burrow structures in deep-sea sediment at the HEBBLE site, western North Atlantic. Deep Sea Res 33:755-790

Alve E (1991) Foraminifera, climatic change and pollution: a study of Late Holocene sediments in Drammensfjord, SE Norway. The Holocene 1:243-261

Alve E, Bernhard JM (1995) Vertical migratory response of benthic foraminifera to controlled oxygen concentrations in an experimental mesocosm. Mar Ecol Prog Ser 116: $137-151$

Barmawidjaja DM, Jorissen FJ, Puskaric C, Van der Zwaan GJ (1992) Microhabitat selection by benthic foraminifera in the northern Adriatic Sea. J Foraminiferal Res 22: $297-317$
Berger WH, Parker FL (1970) Diversity of planktonic foraminifera in deep-sea sediments. Science 168:1345-1347

Bernhard JM (1989) Distribution of benthic foraminifera with respect to oxygen concentration and organic carbon levels in shallow-water Antarctic sediments. Limnol Oceanogr 34:1131-1141

Bernhard JM (1992) Benthic foraminiferal distribution and biomass related to pore-water oxygen content: central California continental slope and rise. Deep Sea Res 39: $585-605$

Bernhard JM (1993) Experimental and field evidence of Antarctic foraminiferal response to anoxia and hydrogen sulfide. Mar Micropaleontol 20:203-213

Bernhard JM (1996) Microaerophilic and facultative anaerobic benthic foraminifera: a review of experimental and ultrastructural evidence. Rev Paléobiol 15:261-275

Bernhard JM, Alve E (1996) Survival, ATP pool, and ultrastructural characterization of benthic foraminifera from Drammensfjord (Norway): response to anoxia. Mar Micropaleontol 28:5-17

Bernhard JM, Reimers CE (1991) Benthic foraminiferal population fluctuations related to anoxia: Santa Barbara Basin. Biogeochemistry 15:203-213

Buzas MA, Culver SJ, Jorissen FJ (1993) A statistical evaluation of the microhabitats of living (stained) infaunal benthic foraminifera. Mar Micropaleontol 20:311-320

Corliss BH (1985) Microhabitats of benthic foraminifera within deep-sea sediments. Nature 314:435-438

Coull BC (1969) Hydrographical control of meiobenthos in Bermuda. Limnol Oceanogr 14:953-957

de Bovee $F$ (1975) La nematofaune des vases autopollués des Iles Kerguelen (Terres Australes et Antarctiques Française). Cah Biol Mar 16:711-720

Diaz RJ, Rosenberg R (1995) Marine benthic hypoxia: a review of its ecological effects and the behavioural responses of benthic macrofauna. Oceanogr Mar Biol Annu Rev 33:245-303

Douglas RG, Woodruff $F$ (1981) Deep-sea benthic foraminifera. In: Emiliani C (ed) The oceanic lithosphere, the sea, Vol 7. Wiley-Interscience, New York, p 1233-1327

Ellison RL (1984) Foraminifera and meiofauna on an intertidal mudflat, Cornwall, England: population; respiration and secondary production; and energy budget. Hydrobiologica 109:131-148

Elmgren R (1975) Benthic meiofauna as indicator of of oxygen conditions in the northern Baltic proper. Merentutkimuslaitoksen Julkaisu Havforskningsinst Skr 239:265-271

Goldstein ST (1988a) Foraminifera of relict salt marsh deposits, St. Catherines Island, Georgia: taphonomic implications. Palaios 3:327-334

Goldstein ST (1988b) On the life cycle of Saccammina alba Hedley, 1962. I Foraminiferal Res 18:311-324

Goldstein ST, Barker WW (1988) Test structure and taphonomy of the monothalamous agglutinated foraminifer Cribrothalammina, n. ge., alba (Heron-Allen and Earland). J Foraminiferal Res 18:130-136

Goldstein ST, Watkins GT, Kuhn RM (1995) Microhabitats of salt marsh foraminifera: St. Catherines Island, Georgia USA. Mar Micropaleontol 26:17-29

Gooday AJ (1986) Soft-shelled foraminifera in meiofaunal samples from the bathyal northeast Atlantic. Sarsia 71 $275-287$

Heip CHR (1980) Meiobenthos as a tool in assessment of marine environmental quality. Rapp PV Reun Cons Int Explor Mer 179:182-187

Heip CHR, Goosen NK, Herman PMJ, Kromkamp J, Middelburg JJ, Soetaert K (1995) Production and consumption of 
biological particles in temperate tidal estuaries. Oceanogr Mar Biol Annu Rev 33:1-149

Heip CHR, Vincx M, Vranken G (1985) The ecology of marine nematodes. Oceanogr Mar Biol Annu Rev 23:399-489

Hill MO (1973) Diversity and eveness: a unifying notation and its consequences. Ecology 54:427-432

Josefson AB, Widbom B (1988) Differential response of benthic macrofauna and meiofauna to hypoxia in the Gullmar fjord basin. Mar Biol 100:31-40

Justic D, Rabalais NN, Turner R, Wiseman WJ Jr (1993) Seasonal coupling between riverborne nutrients, net productivity and hypoxia. Mar Pollut Bull 26:184-189

Kitazato $\mathrm{H}$ (1988) Locomotion of some benthic foraminifera in and on sediment. J Foraminiferal Res 18:344-349

Levin LA, Hugget CL, Wishner KF (1991) Control of deep-sea benthic community structure by oxygen and organic-matter gradients in the eastern Pacific Ocean. J Mar Res 49 $763-800$

Lohse L, Malschaert HFP, Slomp CP, Helder W, Van Raaphorst W (1995) Sediment-water fluxes of inorganic nitrogen compounds along the transport of organic matter in the North Sea. Ophelia 41:173-197

Meyers MB, Fossing H, Powell EN (1987) Microdistribution of interstitial meiofauna, oxygen and sulfide gradients, and the tubes of macro-infauna. Mar Ecol Prog Ser 35:223-241

Meyers MB, Powell EN, Fossing H (1988) Movement of oxybiotic and thiobiotic meiofauna in response to changes in pore-water oxygen and sulfide gradients around macroinfaunal tubes. Mar Biol 98:395-414

Moodley L (1990) Southern North Sea seafloor and subsurface distribution of living benthic foraminifera. Neth J Sea Res 27:57-71

Moodley L, Heip CHR, Middelburg JJ (in press a) Benthic activity in sediments of the northwestern Adriatic Sea: sediment oxygen consumption, macro- and meiofuana dynamics. J Sea Res

Moodley L, Hess C (1992) Tolerance of infaunal benthic foraminifera for low and high oxygen concentrations. Biol Bull (Woods Hole) 183:94-98

Moodley L, Herman, PMJ, Middelburg JJ, Heip CHR (1996b) Subsurface activity of benthic foraminifera. Mar Ecol Prog Ser 145:303-304

Moodley L, Van der Zwaan GJ, Rutten GMW, Boom RCE, Kempers $L$ (in press b) Subsurface activity of benthic foraminifera in relation to porewater oxygen content: laboratory experiments. Mar Micropaleontol

Murray JW (1992) Distribution and population dynamics of benthic foraminifera from the southern North Sea. J Foraminiferal Res 22:114-128

Nyholm KG (1952) Studies on recent Allogromiidae (1): Micrometula hyalostriata n. gen., n. sp., from the Gullmar Fjord, Sweden Contrib Cushman Found Foraminiferal Res 3:14-17, plates 4 and 5

Nyholm KG (1953) Studies on recent Allogromiidae (2): Nemogullmia longevariabilis n. g., n. sp., from the Gullmar Fjord, Sweden. Contrib Cushman Found Foraminiferal Res 4:105-106, plate 18

Nyholm KG (1954) Studies on recent Allogromiidae (3): Tinogullmia hyalina n. g., n. sp., from the Gullmar Fjord, Sweden. Contrib Cushman Found Foraminiferal Res 5:36, plate 7

Editorial responsibility: Otto Kinne (Editor),

Oldendorf/Luhe, Germany
Nyholm KG (1955a) Studies on recent Allogromiidae (4) Phainogullmia aurata n. g., n. sp. Zool Bidr Upps 30 $465-474$, plates $1-5$

Nyholm KG (1955b) Observations on the monothalamous Hippocrepinella alba Heron-Allen and Earland. Zool Bidr Upps 30:475-484, plates 1-5

Nyholm KG (1974) New monothalamous foraminifera. Zoon (Upps) 2:117-122

Nyholm KG, Gertz I (1973) To the biology of the monothalamous foraminifer Allogromia marina. Zoon (Upps) 1:89-93

Rasmussen H, Jørgensen BB (1992) Microelectrode studies of seasonal oxygen uptake in a coastal sediment: role of molecular diffusion. Mar Ecol Prog Ser 81:289--303

Regione Emilia-Romagna (1993) Eutrofizzazione delle acque costiere dell'Emilia-Romagna. Assessorato Ambiente Servizio tutela e Risanamento ambientale, Bologna, Rapporto annuale 1992

Revsbech NP, Jørgensen BB, Blackburn TH (1980) Oxygen in the sea bottom measured with microelectrodes. Science 207:1355-1356

Rudnick DT, Elmgren R, Frithsen JB (1985) Meiofaunal prominence and benthic seasonality in a coastal marine ecosystem. Oecologia 67:157-168

Schröder CJ, Scott DB, Medioli FS (1987) Can smaller foraminifera be ignored in paleoenvironmental analyses? J Foraminiferal Res 17:101-105

Sen Gupta BK, Machain-Castillo ML (1993) Benthic foraminifera in oxygen-poor habitats. Mar Micropaleontol 20 $183-201$

Sen Gupta BK, Shin IC, Wendler ST (1987) Relevance of specimen size in distributional studies of deep-sea benthic foraminifera. Palaios 2:332-338

Soetaert K, Herman PMJ, Middelburg JJ (1996) A model of early diagenetic processes from the shelf to abyssal depths. Geochim Cosmochim Acta 60:1019-1040

Thomsen L, Altenbach AV (1993) Vertical and areal distribution of foraminiferal abundance and biomass in microhabitats around inhabited tubes of marine echiurids. Mar Micropaleontol 20:303-309

Travis JL, Bowser SS (1991) The motility of foraminifera. In Lee JJ, Anderson RO (eds) Biology of foraminifera. Academic Press Limited, London, p 91-156

Tyson RV, Pearson TH (1991) Modern and ancient continental shelf anoxia: an overview. In: Tyson RV, Pearson TH (eds) Modern and ancient continental shelf anoxia. Geological Society London, Special Publication 58:1-24

Van Bruggen JJA, Stumm CK, Vogels GD (1983) Symbiosis of methanogenic bacteria and sapropelic protozoa. Arch Mikrobiol 136:89-96

Van Neuren VJ (1996) A study of the recent history of benthic foraminifera in the northern Adriatic Sea. Unpubl Rep, Netherlands Institute of Ecology, Yerseke

Vidakovic J (1984) Meiofauna of silty sediments in the coastal area of the North Adriatic, with special reference to sampling methods. Hydrobiologia 118:67-72

Wetmore KL (1988) Burrowing and sediment movement of benthic foraminifera as shown by time-lapse cinematography. Rev Paléobiol 2:921-927

Wieser W, Kanwisher J (1961) Ecological and physiological studies on marine nematodes from a small salt marsh near Woods Hole, Massachusetts. Limnol Oceanogr 6:262-270

Submitted: January 31, 1997; Accepted: June 25, 1997

Proofs received from author(s): October 13,1997 